\title{
Copper isotope systematics in seafloor hydrothermal systems: A case study of TAG and Snake Pit fields, Mid- Atlantic Ridge
}

\author{
YANNICK DJEDJROH ${ }^{1}$, OLIVIER ROUXEL $^{1}$, CÉCILE $^{1}$ \\ CATHALOT $^{1}$, LUCIE PASTOR ${ }^{2}$, LAETITIA LEROY ${ }^{1}$, \\ AUDREY BOISSIER $^{1}$, YOAN GERMAIN ${ }^{1}$, SANDRINE \\ CHERON $^{1}$, EWAN PELLETER ${ }^{1}$, FLORIAN BESSON ${ }^{3}$ AND \\ MARIE ANNE CAMBON ${ }^{4}$
}

${ }^{1}$ IFREMER, centre de Brest, REM/GM/LCG

${ }^{2}$ Ifremer, centre de Brest, REM/EEP/LEP

${ }^{3}$ IFREMER, centre de Brest, REM/GM/CTDI

${ }^{4}$ IFREMER, centre de Brest, REM/EEP/LMEE

Presenting Author: ydjedjro@ifremer.fr

Seafloor hydrothermal systems play a significant role in deep ocean metal budgets. Copper $(\mathrm{Cu})$ is a metal of economic interest with potentially toxicity to deep sea biological organisms. Due to its non-conservative property during hydrothermal fluid seawater mixing, it remains unclear whether hydrothermal vents represent an important local or global source of $\mathrm{Cu}$ to the deep ocean. Here we present a comprehensive dataset of $\mathrm{Cu}$ isotope composition of high-temperature vents (fluids and sulfide deposits), low-temperature diffuse vents, hydrothermal plume fall-out and metalliferous sediments. This work focuses on samples which were collected in the Mid-Atlantic Ridge, at the TAG and Snake Pit hydrothermal fields during BICOSE 1\&2 cruises (Ifremer). At TAG, the combination of major and trace element geochemistry and $\mathrm{Cu}$-isotope values of proximal oxidized sediments ( $\delta^{65} \mathrm{Cu}$ from 0.03 to $0.4 \%$ ) compared to hightemperature vent fluids $\left(\delta^{65} \mathrm{Cu}-0.14\right.$ et $0.37 \%$ ), and plume fallout materials collected in sediment traps $\left(\delta^{65} \mathrm{Cu}-0.24\right.$ to $0.07 \%$ ) indicates that quantitative sulfide oxidation within sediments does not impact $\mathrm{Cu}$ isotope signatures. Sulfide-rich metalliferous sediments from Moose site (Snake Pit) display $\mathrm{Cu}$ isotopic values $\left(\delta^{65} \mathrm{Cu} \quad 0.50\right.$ to $\left.0.85 \%\right)$ in the range of both high temperature hydrothermal fluids $\left(\delta^{65} \mathrm{Cu} 0.53\right.$ to $1.01 \%$ ), and chalcopyrite from chimneys $\left(\delta^{65} \mathrm{Cu} 0.55\right.$ to $1.08 \%$ ). This suggests that $\mathrm{Cu}$-isotpoes are not significantly fractionated from source to sink. However, two sediment cores from Beehive (Snake Pit) show variability of $\mathrm{Cu}$ isotopes $\left(\delta^{65} \mathrm{Cu}-0.17\right.$ to 1.37 $\%$ and 0.04 to $0.89 \%$ ) which is interpreted as rapid changes of $\mathrm{Cu}$ sources to the sediment rather than post-depositional modification. Study of sediment porewaters further suggest that diagenesis of hydrothermal sediments may represent a significant source of fractionated $\mathrm{Cu}$ to overlying seawater. 